\title{
Chapter 12 \\ Regulating Fortress Britain: Migrants, \\ Refugees and Asylum Applicants \\ in the British Labour Market
}

\author{
Francesca Calò, Simone Baglioni, Tom Montgomery, and Olga Biosca
}

\subsection{Introduction: From a Multicultural Society to the Fortress Britain}

Any analysis of the legal framework concerning the integration of migrants, refugees and asylum seekers should not be isolated from the socio-economic, political and cultural context of a country. The UK has for some time been portrayed as a multicultural liberal society with some studies showing that the integration of migrants in Britain compares relatively favourably with other countries across various measures of social and political integration (Koopmans 2010; Wright and Bloemraad 2012). The emphasis from the mid-1960s until the beginning of the 2000s has been placed on the 'multicultural' society or 'ethnic pluralism', with different groups co-existing but retaining their independent cultural identities (although placing the blame for racial problems on the minority populations) (Ager and Strang 2008). However, over recent years (according to some scholars from 2000 onwards see for example Joppke 2004) there has been a significant shift in UK public discourses regarding nationhood, prompted initially by race riots in Northern England, ${ }^{1}$

\footnotetext{
${ }^{1}$ For information and details about the race riots and the policy recommendations see Cantle Report (2001).
}

F. Calò

Department of Public Leadership and Social Enterprise, Faculty of Business and Law, The Open University, Milton Keynes, UK

S. Baglioni $(\square)$

Department of Economics and Management, University of Parma, Parma, Italy

e-mail: simone.baglioni@unipr.it

T. Montgomery $\cdot$ O. Biosca

Yunus Centre for Social Business and Health, Glasgow Caledonian University, Glasgow, UK

V. Federico, S. Baglioni (eds.), Migrants, Refugees and Asylum Seekers' Integration in European Labour Markets, IMISCOE Research Series, https://doi.org/10.1007/978-3-030-67284-3_12 
then by concerns over Muslim extremism fostering terrorist threats and exacerbated by the economic crisis and the rise of populist xenophobia alongside anti-migration narratives (Ager and Strang 2008; Geddes and Scholten 2016). From being a multicultural liberal society, which has witnessed a steady growth in immigration, the more recent policies of the UK Government have cultivated a "hostile environment for illegal migrants" (Theresa May speech, 10th October 2013²) where nationhood and assimilation processes became central to policies and political narratives (at least at the national level). To understand why Britain changed from a multicultural society to a hostile one, it is important to explore briefly the recent history of migration.

During an earlier wave of migration, in 1948, the British Government adopted legislation (in the form of the British Nationality Act 1948) ensuring that the UK and Colonies received the status of a British subject and was thus entitled to legal, social and political rights. Colonial migrant labour was used to feed the post-war boom while being employed in the growing industrial and public sectors (Geddes and Scholten 2016; Hansen 2003). After 15 years of colonial migration, moves towards greater restriction emerged in the political agenda as a result of an increasing tension within civil society, the rise of a more populist Conservative Party and the lack of public support for the Labour Party in opposing the introduction of more restrictive legislation. Between 1962 and 1970, citizens of Commonwealth countries that had previously been welcomed as British citizens, became subject to immigration controls and strict regulations were applied in particular to family migration. Over time, these changes were reinforced by further legislation through the British Nationality Act 1981 that steadily reduced the rights of Commonwealth citizens. ${ }^{3}$

More recently, from the mid-1990s up until the present day, large scale net migration, the freedom of movement that comes with EU membership (in particular the enlargement from 2004 onwards) and the rise of populist and anti-immigration movements in the political arena (such as UKIP) fuelling concerns in society about immigration were some of the forces that have shaped the contemporary context of migration in the UK (Geddes and Scholten 2016). As net migration increased EU citizens became an important part of this second wave of migrants. European migration was also accompanied by an incremental increase of non-EU net migration, although non-EU migration had always been based upon stricter and controlling policies that incentivised mainly the arrival of high skilled workers, students and people from former colonies with an ancestral connection to the UK.

During the 2000s, issues of asylum became a central focus of migration debates and the scale of the problem of people being forced to flee their home countries is illustrated by the fact that in 2014 there were more refugees globally than any time

\footnotetext{
${ }^{2}$ Theresa May speech accessible at: https://www.theguardian.com/politics/2013/oct/10/ immigration-bill-theresa-may-hostile-environment

${ }^{3}$ The British Nationality Act of 1981 abolished the 1948 definition of British citizenship and replaced it with three categories: British citizenship, citizenship of British dependent territories and British Overseas citizenship. Of these, only British citizenship provides the right to live in the UK. From 1981 all foreign nationals have had to apply for naturalisation to become British citizens.
} 
since the Second World War (Geddes and Scholten 2016). Strict controls and a hostile environment (as will be fully explored later in this chapter) towards asylum applications were implemented by the British Government since the 2000s and asylum applications, as well as the numbers of those in the end granted leave to remain consequently remained low in comparison with other countries such as for example Germany, Italy and France (Blinder 2017; Eurostat 2018). Policies focused upon controlling borders remain in place to the present day and issues relating to migration have become a permanent fixture of contemporary political campaigns in the UK, from parliamentary elections to referenda.

A fourth phase of the UK migration history can be traced from 2015 onwards. The election of a new Conservative government with a clear commitment to renegotiate the relationship between the UK and the European Union, the rise of populist political movements and the austerity measures that followed the economic crisis in 2008 have, alongside aspects of the campaign to leave the European Union, contributed to the development of a dominant narrative in UK policymaking that emphasises the securing of borders and a more restrictive disposition towards migration more generally (Montgomery et al. 2018; Wallace 2018). Against this background, tighter restrictions in terms of the rights of Non-EU citizens have been implemented in more recent legislation such as the Immigration Acts of 2014 and 2016, encompassing stricter controls in terms of asylum applications, complemented by the opt-out from the European Union refugee relocation schemes and part of the Reception Conditions Directive. ${ }^{4}$

This changing context is part of a long-term process where anti-migrant and anti-refugee discourses, legislations, and policies have dominated policymaking and the media. For example, anti-migration narratives were placed at the centre of Leave campaign in the $2016 \mathrm{EU}$ referendum (Cummings 2017) and they have also been one of the most frequent arguments advanced by the Conservative party in modern elections (see the Conservative Manifesto 2010 and $2015^{5}$ as well as the 2005 campaign led by Michael Howard). Policies and legislation prioritising the control of immigration instead of integration have been favoured, espousing narratives about the negative effect of migration on public services and on the reduction of wages:

In the last decade or so, we have seen record levels of long-term net migration in the UK, and that sheer volume has given rise to public concern about pressure on public services $[\ldots]$ as well as placing downward pressure on wages for people on the lowest incomes. The public must have confidence in our ability to control migration. (Department for Exiting the European Union 2017)

Fresh legislation such as the Immigration Act 2014 and 2016, the opt-out from the EU relocation scheme of Syrian refugees and the recent cases involving the deportation of citizens who were part of the Windrush generation ${ }^{6}$ are some of the examples

\footnotetext{
${ }^{4}$ https://ec.europa.eu/home-affairs/what-we-do/policies/asylum/reception-conditions_en

${ }^{5}$ Parties policy positions and party policies manifesto are available at: https://manifestoproject.wzb.eu/

${ }^{6}$ The Windrush generation refers to immigrants who were invited to the UK between 1948 and 1971 from Caribbean countries. In 2018, these immigrants who had arrived as children on their parents' passports and they never formally became British citizens have been denied services, lost their jobs and faced deportations, raising what it has been called the Windrush generation scandal.
} 
of the environment that has been created in recent years. The negative frame of the debates about migration has also been reflected and reinforced by the way in which the media portrays refugees and migrants. This hostile environment has been mirrored by political uncertainty following the results of the 2015 and the recent 2017 elections. In a landscape of political tumult, marked by reductions in public spending and cuts to welfare, alongside processes of labour market flexibility, increasing levels of inequality have impacted upon the everyday lives of people in the UK, making the context for promoting and implementing integration and inclusion even more challenging.

\subsection{Evolution and Main Stages of Migration and Asylum Law}

Legislation concerning the integration of migrants, refugees and asylum seekers into the labour market has always been intertwined with legislation concerning the accessibility of migrants, refugees and asylum seekers to enter the country. In post-war Britain a key piece of legislation relating to migration was developed in 1948 and it constitutes a milestone in migration law. The 1948 British Nationality Act formally gave all subjects of the Crown including British colonies the right to settle in Britain. Citizens from colonies and the Commonwealth countries were enabled to cement their status as British citizens and access the same formal legal, social and political rights as other subjects of the Crown. This relatively open migration regime lasted until 1962, when consequent to an increasing number of race riots and the rise of right-wing populism, the ruling Conservative Party introduced a new Act (the Commonwealth Immigration Act), restricting the flow of immigration (Geddes and Scholten 2016). The Act distinguished between citizens of the UK and its colonies and citizens of independent Commonwealth countries. The latter became subject to immigration and employment control through the establishment of work vouchers (a type of visa) which reduced the overall numbers of migrants. In addition, only a few of these vouchers were granted to women, setting a precedent (that is still evident today) of preventing women to enjoy the right to family reunification. In 1968 a second Commonwealth Immigration Bill was introduced, again diminishing the rights of people to enter the UK, particularly those British citizens of Indian descent facing persecution in Kenya and Uganda. New immigration controls based upon the 'patriality' rule were then established. This restrictive legislative framework reached its peak in 1971, with the Immigration Act (1971) which distinguished between citizens of the UK and its colonies that had the right to indefinitely being settled in the UK (patrial rule) and those who instead had to apply for work permits to be granted, (definite) right to remain. More modifications regarding the categories of citizens were established in the British Nationality Act (1981). Three typologies of citizens were defined by this legislation, implying the prioritisation of the "white commonwealth": British citizens, British dependent territories citizens and British overseas citizens. New implications for the colonial citizens were then implemented, amending the status of post-colonial peoples from citizens to migrants. 
During the 1980s the issue of migration received less attention from policymakers while it returned to the spotlight from the 1990s onwards. When the New Labour Government (1997-2001) came to power, a more liberal approach to migration was promoted (Hansen 2003; Wright 2017). In 2001, the High Skilled Migrant Programme (renamed the Tier 1 visa) was introduced which established the first points-based system to regulate access to the country. It allowed people entry in relation to factors such as their level of education and earnings, without imposing an upper limit on their numbers. Moreover, work permit (later renamed Tier 2 visa) regulations were loosened to be more responsive to the needs of employers. A key decision of the New Labour period was allowing uncontrolled access to Britain for citizens of the ten member states that joined the European Union in 2004. The UK was one of only three countries that decided not to impose transitional controls on migration from the new EU member states (Wright 2017).

However, in the latter period of the New Labour government, the rhetoric reflected a less open disposition towards migration and marked a return to restrictive policies and legislation. As part of this shift, a five-tier system for labour migration was imposed on Non-EU citizens: Highly skilled migrants (Tier 1), medium skilled migrants (Tier 2), Low skilled and temporary employment visa (Tier 3 - never opened), students (Tier 4) and youth mobility (Tier 5). These more restrictive policies would be continued following the election of the Conservative-led Coalition Government in 2010. Quotas on the numbers of Non-EU arrivals entering the UK (and visas granted to them) were established and a more hostile environment was constructed. The exemplification of this "hostile environment" and legislation were the 2014 and 2016 Immigration Acts. The 2014 Act aimed at facilitating the removal of people without leave to remain, overhauling the appeals process (although following $R$ (on the application of Kiarie) (Appellant) $v$ Secretary of State for the Home Department (Respondent) [2017] UKSC 42 this part of the Act was dismissed), limiting the access to services such as the National Health System (NHS) and housing to people without the leave to remain and tightening controls on immigration status (Wallace 2018). More restrictive changes were included in the Immigration Act 2016, in which penalties (fines and imprisonment) for employers who hire irregular migrants and landlords who rent premises to irregular migrants were established and everyday necessities such as access to a bank account were revoked for irregular migrants.

A parallel but slightly divergent evolution in asylum law can also be distinguished. Until the 1990s the UK had no specific asylum legislation. The right to claim asylum is based upon international law and governments are obliged to provide protection to people who meet the criteria for asylum. The UK is a signatory to these international laws and has long since integrated them into UK legislation. Three pieces of international law can be used to support an asylum application in the UK: the 1951 Geneva Convention relating to the status of refugees, the 1950 European Convention on Human rights (ECHR) and the European Union Asylum Qualification Directive (2003/9/EC) which lays down minimum standards for the reception of asylum seekers. Excluding the integration of these laws, in the UK, from the 1990s onwards policies and legislation were implemented aiming at 
curbing the numbers of asylum seekers and at making life more difficult for those who arrived. While a more open although "managed" migration was promoted between 1997 and 2005 (as described above), measures concerning asylum were mainly aimed at reducing the number of applicants (Mayblin 2016). Measures pertained to three different areas: increasing the control of external borders, the reduction of welfare entitlements and denying access to labour markets and speeding up the legal process (Geddes and Scholten 2016). The presumption that underpinned this legislation (enacted both by Labour and Conservative Governments) was that many asylum seekers were not genuine (and were instead "bogus") and thus were undeserving of welfare state support or should not be allowed access to labour markets at least until they were verified as "genuine" (Geddes 2003).

Although the Asylum and Immigration Appeals Act of 1993 integrated the United Nations Convention 1951 definition of asylum claims, it also constituted the first act that reduced the benefit entitlements of asylum applicants, introduced tighter controls on the application process and involved the detention of asylum seekers. The Asylum and Immigration Act of 1996 extended penalties associated with being an irregular migrant and removed access to welfare benefits for "in-country" applicants as opposed to applying at the port of entry and, in 1999, support for asylum seekers ( $£ 35$ per week using mainly vouchers) was implemented. A no-choice dispersal system across the UK for destitute asylum applicants was enacted to lessen the burden on the London and South East regions. Through the Nationality, Immigration and Asylum Act of 2002 an asylum architecture was created to regulate induction, accommodation and removals including the National Asylum Support Service (NASS) (now the UK Visas and Immigration - UKVI) which assumed responsibility for arrivals, housing and economic support provision (Meer et al. 2018). In 2002, the right to access labour markets for asylum applicants was also removed and to this day it is extremely difficult for asylum seekers to be integrated into the job market (Mayblin 2016). Furthermore, the indefinite leave to remain (the right to stay in the country indefinitely) for refugees was modified into a 5-years leave to remain status with a reassessment of the situation in the country of origin taking place at the end of that period (Bloch 2008). After 2010, the Conservative-led Governments maintained an emphasis on restricting asylum. The focus on speeding up the asylum process and the consequent lack of appropriate time to seek and obtain legal assistance led the British High Court to find the fast-track system unlawful because of an unacceptable risk of unfairness for asylum seekers who have lived through specific trauma. In another example of ever restrictive access, the UK Government also opted out of the EU relocation schemes for Syrian refugees in order to reduce the number of people that the UK would receive (Geddes and Scholten 2016). This brief overview of the main stages of migration and asylum law reveals that UK Governments from the 1990s onwards aimed first at "managing" migration and afterwards focused upon "controlling" migration, imposing a mix of increased border control and reduced internal rights which have contributed to the emergence of the legislative and institutional frameworks of today.

To understand the complex rules that regulate contemporary immigration to the $\mathrm{UK}$, it is useful to provide a brief overview of the right to enter and to have leave to 
remain in the country for each category of migrants (Non-EU migrants, asylum seekers and refugees that are part of relocation schemes). Each of these categories of migrants must adhere to different regulations and procedures.

\subsubsection{Non-EU Arrivals}

Non-EU migrants have the right to enter the country (for a period longer than 6 months) if they have a valid entry clearance based upon a visa. A visa has to be released in the country of origin and this can be issued under different schemes which will be fully discussed later in this chapter. The visa can eventually be renewed in the UK based upon valid documentation. After spending a specific continuous period lawfully in the country (from 5 to 10 years depending on the schemes), providing specific documentation, undertaking language and culture tests and presenting specific characteristics (such as not being an illegal entrant), Non-EU migrants can apply for the indefinite leave to remain. Afterwards, they are eligible to apply for British citizenship.

\subsubsection{Asylum Seekers and Refugees Status}

Very different regulations are applied to asylum seekers in the UK. For someone to claim asylum in the UK, they are required to present themselves to the offices of the UK Border Agency immediately upon their arrival into the country (claiming UK asylum from outside the UK is not legally possible). A person may apply for asylum in relation to the 1951 Convention through fear of persecution in their own country or may instead make a "human rights claim" under the 1950 ECHR, indeed an asylum seeker may make a human rights claim as part of a refugee claim. In terms of human rights, an asylum seeker may make a claim in accordance with Article 3 of the ECHR which protects individuals from torture, inhumane and degrading treatment or in accordance with Article 8 of the ECHR which protects the person's right to a personal and family life. Following a pivotal court case (Regina (Razgar) v Secretary of State for the Home Department 2004) those seeking asylum according to their right to a personal and family life have their claims heard in relation to the "Razgar Test" which aims to balance the rights of the person seeking asylum with the right of the state to effectively control its borders. The Razgar test includes a five-stage test comprehensive of the following issues:

1. Does the [refusal] amount to an interference by a public authority with the exercise of the applicant's right to respect for his private or (as the case may be) family life?

2. If so, will such interference have consequences of such gravity as potentially to engage the operation of article 8 ? 
3. If so, is such interference in accordance with the law?

4. If so, is such interference necessary in a democratic society in the interests of national security, public safety or the economic well-being of the country, for the prevention of disorder or crime, for the protection of health or morals, or for the protection of the rights and freedoms of others?

5. If so, is such interference proportionate to the legitimate public end sought to be achieved?

Once a person makes a claim for asylum they are required to undergo a "screening interview" which involves providing basic information including why the person is seeking asylum and their route of travel to the UK (to assess whether the persons' claim for asylum is the responsibility of another country under the Dublin regulations ${ }^{7}$ ). At the screening interview, a triage process is implemented. According to the Asylum operating model (2013), the purpose of 'triage' is to identify 'types' of cases and assess them based on the length of time it is likely to take to decide the claim and to finally resolve the case. The triage establishes if the case can be considered an expedited case or not. Expedited cases cover detained fast-track cases and cases where a person will be sent to a European country through which they passed en route to the UK to have the case decided there ('third country cases'). In a non-expedited case, three characteristics will determine the type of cases: the length of time a claim; the likelihood that the claim will be granted; and, thirdly, if refused, the speed at which removal can take place. If asylum applicants are considered destitute, they are eligible for accommodation inside the UK dispersal scheme and a payment of $£ 37.65$ per week to cover their essential living needs (ELN).

If an asylum application is accepted, there are two successful forms of asylum, one being "refugee status", the other "humanitarian protection", in both situations the person is awarded limited leave to remain (lasting 5 years), following which they can apply for indefinite leave to remain in the UK and consequently British citizenship. Once asylum seekers have gained leave to remain, they are obliged to leave their accommodation - if provided inside the dispersal scheme - within 28 days and register for administrated welfare support on the same basis as British citizens. For those whose applications are refused, some applicants may have the opportunity to appeal this decision which involves taking their case through a process of tribunal and in those cases where there are challenges as to how the law has been applied, to higher courts, including the UK Supreme Court and the European Court of Human Rights.

\footnotetext{
${ }^{7}$ An overview of the screening interview is available in the policy guidance "Asylum Screening and routing" published by the Home Office in 2018: https://assets.publishing.service.gov.uk/government/uploads/system/uploads/attachment_data/file/700624/screening-and-routing-v1.0ext.pdf
} 


\subsubsection{Refugees Under Relocation Schemes}

Four resettlement schemes fully funded by the UK's Official Development Assistance (ODA) budget were provided by the UK government in the period 2014 to 2016: the Syrian Vulnerable Persons Resettlement Scheme (VPRS), the Gateway Protection Resettlement programme, the Mandate Scheme and the Vulnerable Children Resettlement Scheme from the Middle East and North Africa (MENA). People who can apply to these schemes are identified by the United Nations and brought directly to the UK (Home Office 2017b). The VPRS is a joint scheme between the Home Office, the Department for International Development and the Ministry of Housing, Communities and Local Government aiming at relocating 20,000 exclusively Syrian persons by 2020 . The UK sets the criteria and then UNCHR identifies and submits potential cases (Mulvey 2015). The Home Office screens the potential cases and afterwards, a full medical assessment is conducted by the International Organisation of Migration (IOM). Full details of cases are sent to the local authority and after eligibility to enter the UK has been granted, visas and leave to remain for 5 years are issued under humanitarian protection (Home Office 2017b). At the time of writing, 10,538 people have been involved in the VPRS. A similar process has been established in the Gateway Protection Resettlement programme co-funded by the European Union, which aims at offering a legal route for up to 750 refugees to settle in the UK each year and for the Vulnerable Children Resettlement Scheme which aims at supporting vulnerable and refugee children at risk and their families. Up to February 2018, 539 people have been resettled with the MENA scheme. Finally, the Mandate Scheme is applicable to refugees that have been recognised as such by the UNHCR (from applications in their country of origin or in the country where they were recognised as refugees). Although Mandate Scheme refugees have no entitlement to asylum in the UK, the UK Border Agency accepts that in determining the asylum claim of a Mandate Scheme refugee the decision maker must give mandate status due weight and take it into account when assessing credibility and determining the risk on return.

\subsection{Legislation Concerning Migrants, Refugees and Asylum Seekers Integration into Labour Market}

The right to work is a restricted privilege to which migrants are granted unequal access in relation to citizens and in relation to each other. Some migrants are able to obtain visas to work in the UK relatively easily, while for others working is prohibited (Mayblin 2016). The next section will outline the different legal statuses and the rights to work in the UK depending on the legal status of migration. 


\subsubsection{Non-EU Arrivals}

The Non-EU migrants (excepted asylum seekers and refugees) can apply to various visas to access the labour market in the UK. Three different visa tiers have been established and are currently operating: Tier 1, Tier 2 and Tier 5. Non-EU migrants can apply before arriving to the UK for Tier 1 visas if they are willing to open a business activity (with investment of at least $£ 50,000$ ), they represent an exceptional talent or promise in the field of science, humanities, engineering, medicine, digital technology or the arts (endorsement has to be granted by the Home Office), they aim to invest at least $£ 2$ million in the UK or if they are graduate entrepreneurs with an endorsed idea from the Department of International Trade or from a UK Higher Education institution. Until 2015, high skilled migrants achieving a high score in the points-based system ${ }^{8}$ were also entitled to apply to Tier 1 . However, the programme has since been closed and only extensions are considered. A Tier 2 visa can be requested if a non-EU migrant has received a skilled job offer by one of the recognised and licenced sponsors. Sponsors must offer a salary higher than $£ 30,000$ or a job that is included in the shortage occupation list. ${ }^{9}$ The Tier 2 visa also includes migrants who are involved in intra-company mobility, are ministers of religion or are an elite sportsperson. Non-EU migrants can apply for the Tier 5 visa if they are willing to volunteer in a charity, they have been sponsored to work as a sportsperson or creative worker, they are aiming to participate in a work exchange programme for a short time, they are employed under international law (e.g. working for a foreign government) or they are working for a religious order. The Tier 5 visa also offers the possibility for young people between 18 and 30 years of age from specific countries ${ }^{10}$ to spend a period up to 2 years in the UK (Youth Mobility Scheme).

Although eligibility rules are very different across the different schemes, all nonEU migrants must have a valid clearance for entry under these routes. The majority of the visas request a specific endorsement from a public sector organisation (e.g. the Home Office) or a sponsorship from a list of licensed companies. When an endorsement or the sponsorship is not requested, a high level of skills is necessary, an amount of investment is requested (such as for Tier 1) or there are restrictions concerning the eligible countries (such as for the Youth Mobility Scheme). These regulations clearly increase the barriers to access the UK labour market for non-EU migrants. Most non-EU migrants who are subject to immigration control are also unable to access "public funds" (such as jobseekers' allowance or tax credits), although they can use public services like the NHS and education. Finally, through the Immigration Act 2014 and 2016, an NHS surcharge (Immigration Health

\footnotetext{
${ }^{8}$ In order to be eligible for a visa in any of the five tiers the applicant must pass a points-based assessment. In work visa applications, points are generally awarded according to the applicant's ability, experience and age.

${ }^{9}$ The Shortage Occupation List revised in July 2019 is available at: https://www.gov.uk/guidance/ immigration-rules/immigration-rules-appendix-k-shortage-occupation-list

${ }^{10}$ Australia, Canada, Japan, Monaco, New Zealand, Hong Kong, Republic of Korea, Taiwan.
} 
Surcharge) to cover the entire period of the visa has been introduced in the immigration application for all non-EU migrants.

\subsubsection{Asylum Seekers}

A completely different system and right to work has been established concerning asylum seekers. Asylum policy has been identified as institutionally exclusionist, given that the restriction of rights demarcates asylum seekers as "other" and undeserving (Bakker et al. 2016). According to the Immigration Act of 1999, asylum seekers are explicitly excluded from the labour market. Up until 2002, asylum seekers could request permission to work after 5 months of awaiting their application, but in 2002 this period was extended to 12 months. Moreover, the pending period should not be a consequence of mistakes made by the asylum seeker in the application ("fault of the claimant") (Home Office 2017a). This is in contradiction with the Reception Conditions Directive (COM[2011] 320 final) published in 2011 which only allows a labour market restriction for 6 months (Bales 2013). However, the UK government, as explored in the case law section, rejected the 2011 Reception Conditions Directive. After the 12-month period lapses, asylum seekers can only apply for jobs specified under Tier 2 of the Shortage Occupation list. The Tier 2 restriction was justified by the UK Government due to the legislation on labour market access for Non-EU migrants (explored above). It is therefore very difficult for asylum applicants to comply with the Tier 2 shortage occupation lists and this clearly affects their opportunities for integration, and consequently has an impact on their health and connectedness (particularly of women) (Mayblin 2016; Mulvey 2015). In addition, asylum seekers are also precluded from self-employment and starting a business according to Immigration Rules part 11B (Reception Conditions for Non-EU Asylum Applicants).

Exclusion from employment makes the asylum seekers fully dependent on the state for their means of their existence (Bales 2013). In addition, they are also immediately excluded from the provision of mainstream benefits (such as for example Child Benefit, Disability Living Allowance). Only in those cases where the asylum applicant is considered to be destitute or is likely to become destitute with the next 14 days (section 95 of Asylum Act 1999), do they receive support from the Home Office. Payments to meet essential living needs (equivalent to $£ 37.75$ per week) and/or accommodation on a no-choice basis are provided. There is a somewhat different situation for refused asylum seekers: they are generally not entitled to any help, and their accommodation and public welfare support is removed. However, if they demonstrate that they are taking action to leave the country or they can demonstrate that they cannot return to their home due to the situation in their country of origin they could receive basic shelter and a lower level of support. 


\subsubsection{Refugees}

Migrants granted refugee or humanitarian protection statuses (including refugees who are resettled as part of the VPRS) are entitled to work without any restrictions (both as an employee or self-employed) and thus have the same right to work as British citizens. However, the definite leave to remain for 5 years has been identified as a barrier to labour-market access due to the uncertainty surrounding the long-term future of a refugee in employment (Bloch 2008; Stewart and Mulvey 2014). Refugees are eligible for mainstream benefits such as the most recent Universal Credit reform. ${ }^{11}$ However, new refugees could face a period without any income due to the specific timeframe of the welfare benefit and the gap with the transition period of 28 days (APPG 2017). Newly recognised refugees are able to apply for an interest-free integration loan to negotiate this period where there is a risk of destitution. The Home Office is responsible for accepting the request while the Department for Work and Pensions is responsible for the payment and the recovery of the loan. Different experiences in terms of welfare entitlement are faced by refugees that are part of the Vulnerable Persons Resettlement Scheme. They, in fact, receive a pre-departure cultural orientation and they are immediately provided with accommodation, a welcome pack, an allowance and support for health and education services.

Table 12.1 summarises the rights to residence, work and welfare access that the different migrants are entitled to.

\subsubsection{Constitutional Milestones Case-Law on MRA Access to Labour and Labour Markets}

Constitutional milestones in case-law on MRA access to labour markets have been particularly significant in the field of asylum because of the differences in their right to work in comparison with refugees, migrants and citizens (Bales 2013).

Asylum seekers are explicitly excluded from the UK labour market until their claim has been pending for 12 months or until they have been granted refugee status. This restriction contradicts Article 15 (1) of the amended EU Reception Conditions Directive published in June 2011 in which asylum seekers can access labour markets after 6 months. The UK Government, in fact, decided to opt out from the EU Directive amendment. Moreover, after a 12-month period, asylum seekers are limited to applying for jobs specified under Tier 2 of the Shortage Occupation List. This decision was introduced in September 2010 following the case of ZO (Somalia) and others: (Respondents) v Secretary of State for the Home Department (2010) UKSC 36. ${ }^{12}$ The Supreme Court decided that restricting employment to

\footnotetext{
${ }^{11}$ Universal credit is a social security benefit introduced in 2013 to replace six different benefits and tax credits.

${ }^{12}$ Accessible at: https://www.supremecourt.uk/cases/docs/uksc-2009-0151-judgment.pdf
} 
Table 12.1 Rights entitlement for migrants

\begin{tabular}{|c|c|c|c|}
\hline Definition/status & \begin{tabular}{|l|} 
Right to \\
residence
\end{tabular} & Right to work & Welfare rights \\
\hline $\begin{array}{l}\text { Asylum seeker: a person } \\
\text { who has applied for asylum } \\
\text { and whose application has } \\
\text { not yet been decided }\end{array}$ & $\begin{array}{l}\text { Yes, whilst } \\
\text { their } \\
\text { application is } \\
\text { considered }\end{array}$ & $\begin{array}{l}\text { No (curtailed since } \\
\text { 2002). Can apply for } \\
\text { permission to work } \\
\text { after } 1 \text { year if the } \\
\text { delay of initial claim } \\
\text { is not their fault - } \\
\text { Only Tier } 2 \text { shortage } \\
\text { list }\end{array}$ & $\begin{array}{l}\text { Basic accommodation and } \\
\text { public welfare support. } \\
\text { Must be destitute and } \\
\text { willing to accept no-choice } \\
\text { dispersal policy }\end{array}$ \\
\hline \multirow[b]{2}{*}{$\begin{array}{l}\text { Humanitarian protection: } \\
\text { a person whose case does } \\
\text { not fit the refugee criteria } \\
\text { but who is given permission } \\
\text { to enter or remain in the UK } \\
\text { because they need } \\
\text { protection from harm by } \\
\text { others }\end{array}$} & Yes & \multirow[t]{2}{*}{ Yes } & \multirow{2}{*}{$\begin{array}{l}\text { Access to welfare rights on } \\
\text { the same base of UK } \\
\text { citizens. They need to wait } \\
3 \text { years to access financial } \\
\text { support for universities. }\end{array}$} \\
\hline & $\begin{array}{l}\text { Granted for } \\
5 \text { years in first } \\
\text { instance }\end{array}$ & & \\
\hline \multirow{2}{*}{$\begin{array}{l}\text { Refugee: a person who has } \\
\text { received a positive decision } \\
\text { on their asylum claim }\end{array}$} & Yes & \multirow[t]{2}{*}{ Yes } & \multirow{2}{*}{$\begin{array}{l}\text { Access to welfare rights on } \\
\text { the same base of UK } \\
\text { citizens. }\end{array}$} \\
\hline & \begin{tabular}{|l|} 
Granted \\
5 years \\
temporary \\
leave to remain \\
(since 2005) \\
\end{tabular} & & \\
\hline \multirow{2}{*}{$\begin{array}{l}\text { Refused asylum seeker: a } \\
\text { person whose asylum claim } \\
\text { has been refused }\end{array}$} & No & \multirow[t]{2}{*}{ No } & \multirow[b]{2}{*}{$\begin{array}{l}\text { Not generally entitled to } \\
\text { support. Accommodation } \\
\text { and Public Welfare support } \\
\text { removed. Basic shelter and } \\
\text { support may be available } \\
\text { for some hard cases }\end{array}$} \\
\hline & $\begin{array}{l}\text { Expected to } \\
\text { return to their } \\
\text { country of } \\
\text { origin }\end{array}$ & & \\
\hline $\begin{array}{l}\text { Non-EU migrant: a person } \\
\text { who came to the UK for } \\
\text { work and study under a visa } \\
\text { programme }\end{array}$ & $\begin{array}{l}\text { Yes. Granted } \\
\text { for the time of } \\
\text { the Visa }\end{array}$ & $\begin{array}{l}\text { Depending on the } \\
\text { Visa (Tier for work) }\end{array}$ & $\begin{array}{l}\text { Education and NHS (NHS } \\
\text { Surcharge) }\end{array}$ \\
\hline
\end{tabular}

Adapted from Dwyer et al. (2016)

refused asylum seekers, who had made further applications on their claim, was against the Reception Conditions Directive. This decision would have allowed asylum seekers access to the UK labour market after 12 months from their application or appeals. Therefore, the Coalition Government decided to impose the Tier 2 restriction Shortage Occupation List as the only employment possibilities available to asylum seekers. The list includes only very specific high skilled occupations such as for example classical ballet dancers who meet the standard required by internationally recognised United Kingdom ballet companies, physical scientists, engineers or doctors. It is thus evidently challenging for asylum seekers to access the UK labour market once the 12 month period lapses (Mayblin 2016).

According to Section 95 of the Immigration and Asylum Act 1999, asylum seekers are not only excluded from the labour market, but they are also unable to access 
national welfare benefits. They are provided with cash/vouchers support and/or accommodation if they are considered destitute. According to Randall (2015) destitution has been defined in two different ways. The Home Office under Section 95 of Immigration and Asylum Act 1999 defines destitution as lacking access to adequate accommodation or the inability to meet essential living needs (ELN). Other research instead has defined destitution as lacking shelter, food, heating, lighting, clothing and basic toiletries or having an income level so low that it is not possible to access minimum material necessities. Until $R$ (Refugee Action) $v$ Secretary of State for the Home Department [2014] EWHC 1033 the definition of essential living needs was not clear (Bales 2015). Consequent to the decision of the Secretary of State in 2013 of freezing the income support to asylum seekers (equivalent at that time to $£ 36.62$ per week for a single person), Refugee Action - a charity organisation in England and Wales - sought judicial review of the decision. The judge responded that the rate was not enough to guarantee an adequate standard of living as stipulated by the European Reception Conditions Directive and it did not include items such as household goods, nappies and non-prescription medical goods considered to be essential (Bales 2015). However, after reconsideration by the Secretary of State, the decision was to maintain the same cash support (the rate was increased at the beginning of 2018 from $£ 36.95$ to $£ 37.75$ according to the Asylum Support Amendment Regulations 2018 No.30). Although the judgement of this case is limited to the confines of this decision, the restrictions on which the asylum support system is built were questioned. The lack of an adequate rate of support for essential living needs affects the integration of asylum seekers, often inducing them to live in poverty and can often increase their risk of exposure to forced and irregular employment.

The third case, and the most recent, dealt with what has become known as the 'deport first, appeal later' provision, an amendment to the 2002 Nationality, Immigration and Asylum Act, which came into force as part of the Immigration Act 2014. The power to remove a person from the UK pending his/her deportation appeal, where such removal would not be unlawful, was thus established. The provision specifies that the grounds upon which such power may be exercised is that removing the person to the country or territory to which the Home Office proposes to remove them would not cause them to face 'serious irreversible harm.' In the case of $R$ (on the application of Kiarie) (Appellant) $v$ Secretary of State for the Home Department (Respondent) [2017] UKSC 42, the Supreme Court in March 2018 found this section unlawful. The Court's principal concerns highlighted the barriers for deportees to secure, fund, and instruct legal representatives from abroad, the ability to obtain expert evidence where relevant, and, crucially, the ability of the individual to give effective oral evidence. Therefore "deport first, appeal later" was considered to be a breach of the procedural requirements of Article 8 of the European Convention on Human Rights, that is, the right to an appeal against a decision affecting an individual's right to respect for their private and family life. Thus, asylum seekers as well as refugees and migrants who are awaiting the response of the 
Home Office concerning their appeals, are allowed to stay in the country whilst their appeal is being processed.

\subsubsection{Anti-discriminatory Legislation}

Another piece of legislation which deals with the integration of migrants, refugees and asylum seekers into the labour market concerns anti-discriminatory and anti-exploitation laws (explored in the next paragraph). The UK race relations model has historically been influenced by managing diversity through racial equality, non-discrimination acts and limiting numbers (Scholten et al. 2017). The first attempts to deal with the potential for racial conflict and to tackle racial discrimination can be traced back to the 1960s and 1970s. Three Race Relations Acts (1965, 1968, 1976) were enacted, aiming at banning discrimination on the basis of race, colour or ethnic origin through legal sanctions. Regulatory agencies were also established to promote greater equality of opportunity and access to employment, education and public facilities. However, according to several studies, these goals remained unfilled (Schuster and Solomos 2004).

Only after the election of the Labour government in 1997, were race relations modified, through the 2000 Race Relations (Amendment Act) which enforced on public authorities a new duty to promote racial equality. However, officials from the Home Office that make decisions on immigration cases were excluded. The persistent underemployment of minority ethnic groups resulted in the formation of the Ethnic Minority Employment Task Force in 2003. In 2007 the Equality and Human Rights Commission (EHRC) had taken on the responsibilities of the Commission for Racial Equality and the 2010 Equality Act superseded the four Race Relations Acts, combining everything into a broader framework (Geddes and Scholten 2016). The Equality Act 2010 sets out nine protected characteristics which are: age; disability; gender reassignment; marriage or civil partnership (in employment only); pregnancy and maternity; race; religion or belief; sex; and sexual orientation. The 2010 Act encompasses the protections previously provided by legislation including the Equal Pay Act 1970, the Race Relations Act 1976 and the Disability Discrimination Act 1995. Finally, included in the 2010 Act was a "public sector equality duty" which harmonised some of the existing duties not to discriminate based upon race, disability and gender in public sector organisation. However, criticisms of the Equality Act highlighted that including race alongside other categories has watered down the protection of minorities in terms of discrimination in the labour market. 


\subsubsection{Anti-exploitation Legislation}

Irregular migrants and asylum seekers that face a limited access to benefits and a restriction to the rights to work are often involved in irregular and informal sectors of employment (Dwyer et al. 2016). However, also refugees and regular migrants could be exposed to severe exploitative labour because of the high barriers they face in finding employment (Dwyer et al. 2016). Since 1996, it has been possible to prosecute UK employers for hiring irregular immigrants. Sanctions were further strengthened in 2004 and 2008, up to the arrival of the Immigration Act of 2016 which again increased penalties. Today, those employers who have "reasonable cause to believe" that an employee has no right to work as a consequence of their immigration status can face up to 5 years in prison and an unlimited fine. Although some of the measures are directed at employers, they are likely to affect workers who may become more exploited through employers seeking to manage risks by lowering wages and/or increasing working hours (Dwyer et al. 2016). Unauthorised workers themselves, who became criminalised for the new offence of "illegal working" would also face deportation without appeal if they did not have the right to remain in the UK. The UK, then, is characterised by a strong degree of state intervention to maintain formal labour markets. This legislation, more than tackling informal employment, seems to increase the barriers to access labour markets and indirectly affect the conditions of employment. This also confirms that a major focus, in fact, has been placed on border enforcement and the reduction of irregular migrants instead of improving working conditions. Trade unions and community organisations have thus asserted some role in campaigning and promoting better working conditions for migrants and ethnic minorities. For example, the Living Wage campaign in London is a key case example of unions and community organisations working together to improve working conditions for a mainly migrant group of workers.

\subsection{Integration in the UK Labour Market: Institutional Challenges}

The lack of a national strategy for the integration of migrants, refugees and asylum seekers is one of the main institutional challenges and barriers that can be identified in the UK context (MacIver 2016). Integration has, in fact, remained notably absent from policy, at least since 2010 (Meer et al. 2018). Refugees are the only category for which the UK Government has introduced an integration strategy in 2000 (Equal Citizens) that aimed at supporting refugee access to jobs, benefits, accommodation, health, education and language classes (Mulvey 2015). In addition, initial policies were aimed at supporting the involvement of third sector organisations in service provision (Cheung and Phillimore 2017). A second refugee integration strategy was developed in 2005, firstly through the Strategic Upgrade of National Refugee 
Integration Service (SUNRISE) and then via the Refugee Integration and Employment Service (RIES). These two programmes aimed at enabling integration through the signposting to mainstream services across key social policy areas. Both programmes were operated by the Refugee Councils and local authorities and they helped to assist refugees to recognise their own skills and experience, improving their ability to access employment services (Bloch 2008). However, after the General Election in 2010 and due to the austerity measures that followed, the integration programmes were closed, placing the responsibility of integration fully in the hands of local government and communities (Bales 2013). While a range of government departments have been under pressure to reduce their budgets, migrants, refugees and particularly asylum seekers were targeted as a relatively easy area for austerity measures. Asylum seekers are unable to vote, unable to work and are often portrayed negatively in the media (Darling 2016; Sales 2002). Thus, instead of focusing on integration policies, the major focus of the UK Government has been on increasing barriers at entry, investing in removals and creating an inhospitable and difficult environment for all migrants. In recent years the policy emphasis shifted from separate and specific immigrant integration policies to the broader social inclusion and mobilities priorities (van Breugel and Scholten 2017).

A dark picture comes out also from the potential enablers of integration into labour market. The UK Government identifies language learning and education as key facilitators of the integration of MRA (Meer et al. 2018). Acquisition of language has been identified as central to obtain employment, increase social connectedness and achieve positive health and well-being (Bakker et al. 2016). However, despite the focus of the UK Government on English-language abilities in its policies, funds to provide courses have been reduced. Asylum seekers were excluded from free access to English courses in England (Mulvey 2015) and restrictions on the provision of courses for refugees were also established. According to Court (2017), between 2008 and 2015, there was a 50\% funding reduction of English as a Second or Other Language (ESOL) classes. Increasing waiting lists and a lack of provision in the local community were among some of the effects of this funding reduction. Although a $£ 10$ million funding scheme has been announced in 2016 for providing free English classes, these courses are only accessible to Syrian refugees who arrived through the VPR Scheme (MacIver 2016). For the other refugees there are no specific funding streams except those that are dedicated to any other individuals who meet the eligibility criteria. As described above, education is one of the areas devolved to subnational constituent nations of the UK. Thus, the level of access to education differs across these nations. In Scotland, for example, education policies have worked alongside Scottish Government integration approaches to provide access for both refugees and asylum seekers to education (Meer et al. 2018). All children and young people from different backgrounds including asylum seekers and refugees have universal access to compulsory education in Scotland. For those over the age of 16 , fees for attending college and studying full or part-time 
course are waived. In addition, ESOL classes are offered to all migrants independently from their legal status and programmes to integrate local communities and migrants through English language courses have been provided.

Concerning education, the UK exercised its right under Protocol 21 not to opt-in to the Qualification Directive (Directive 2011/95/EU). Thus, the UK does not apply the Directives with respect to procedures for the recognition of qualifications, in particular, the equal treatment between refugees and nationals and access to schemes for the assessment and validation of prior learning. The UK has a National Recognition Information Centre (NARIC) who is responsible for providing information and advice on the skills and qualifications of all migrants and it provides international qualifications conversion. Support for university access is fragmented and dependent upon the legal status of the migrant. For example, refugees have the same access to University as British students (with the same fees as home students) and scholarships alongside loans are often offered. Migrants that arrive with the aim of studying in the UK have to pay a higher level of fees than home students and do not have access to the same levels of financial support (APPG 2017).

Some vocational programmes of work placement and job intermediation initiatives have also been implemented. Examples of this are the Phoenix Mentoring Project or the Bridges Programmes which arrange short-term placement and mentoring activities. The Phoenix Mentoring project in Newcastle aims at supporting young asylum seekers and refugees between 16 and 25 years old in a process of learning and development based upon a one-to-one mentor support programme. The Bridges Programmes based in Scotland aims at providing employability support to migrants, refugees and asylum seekers, investing in further education, short work placement programs (not paid placement) and vocational training. However, the risk of losing Job Seekers Allowance during the work placement programmes has been identified as a disincentive for participation in vocational schemes (MacIver 2016) and the entry criteria ascribed by the professional standards required in the UK, the difficult process of re-qualifications and examinations have been identified as barriers to access the labour market in these sectors (Piętka-Nykaza 2015). Some training schemes have been developed to incentivise refugees to be self-employed and run their own businesses. The Refugees into Business scheme, for example, supported applicants in each of the steps necessary to set up a small enterprise. However, the lack of a national strategy and policies in terms of educational access and training, multiplies the risk of creating a fragmented and project-based response to integration issues, a response that risks being insufficient to address the complex and multifaceted path of inclusion. 


\section{Scotland}

Migration is one of the policy fields where the divergence between Westminster and Holyrood (Scottish Parliament) is evident (Mulvey 2015). Outside of the borders issues and the naturalisation process, most policies that could affect integration processes, such as health, education, some aspects of welfare and housing are devolved. Recently, a narrative of a dynamic two-way integration process and engagement was promoted in the New Scots 2014-2017 strategy and an integration infrastructure based upon this dynamic two-way process was advocated by the Scottish Government (Meer et al. 2018). In fact, the recent New Scots Refugee integration 2018-2022 strategy defined clearly the integration path detailing the responsibility both on the displaced and the settled population in different fields such as employability, welfare, housing, education, health and social connections. A specific Race Equality Framework for Scotland was also enacted in 2016 to promote race equality and tackle racism and very recently a campaign about the integration of migrants (\#WeAreScotland) has been launched.

Concerning asylum applicants, the Scottish Government decided to focus on integration from the moment asylum seekers arrive in Scotland and not only when refugee status has been granted. This means that while rights to work and to access mainstream benefits are still restricted for asylum seekers (due to the Westminster immigration rules above explored), education, healthcare, and free English courses are instead available not only to refugees but also to asylum applicants and rejected asylum seekers. However, for some services the jurisdiction remains contentious (Meer et al. 2018), for example, in the housing sector, while the Home Office is responsible for the dispersal accommodation, the standards of housing are regulated by the Scottish Government.

Multi-agency networks that include several different stakeholders have been established in Scotland and in particular in Glasgow to promote services aimed at integrating MRA (Meer et al. 2018). For example, the Holistic Integration Service has been provided at regional level through a partnership of non-profit organisations and educational organisations and is aimed at supporting people that have recently been granted the refugee status, facilitating finding accommodation, applying for welfare benefits and accessing the labour market (see Strang et al. 2018 for more information). Two specific programmes were also promoted at a regional level to support integration into employment: the Refugees into Teaching in Scotland programme implemented between 2004 and 2011 and the New Refugee Doctors Project from 2016, subsequent to the UK wide Refugee Doctors scheme. Another initiative, the Bridges programme (non profit organisation) was also established from 2002 aiming to connect employers and migrants, refugees and asylum seekers, to introduce people to the labour market. These are just some of the examples of the programmes sustained in Scotland which are useful to highlight the different approach that has been endorsed. However, a fragmented approach with diverse initiatives and projects promoted by different organisations has been also identified as a barrier to long-term integration, with the risking of simply moving people from one project to another without a long-term outcome (Meer et al. 2018). 


\section{Wales}

Tensions between the levels of governance involved in migration policy can be evidenced also in the Welsh case. Although the Welsh government is not responsible for UK migration policies, as in the case of Scotland it is responsible for several devolved competencies such as housing, social services, education and healthcare. Contrary to Scotland, Wales has not yet developed an integration strategy, but it has published a specific approach towards migrants, refugees and asylum seekers in several pieces of legislation, such as the Well-Being of Future Generations (Wales) Act 2015, the Social Services and Well-Being (Wales) Act 2014, or in policies plans such as the Community Cohesion and Refugee and Asylum seeker Delivery plan (Spencer and Sanders 2016). The Social Services and Well-Being (Wales) Act established that people who do not have leave to remain in the UK are not excluded from the provisions of services. In the Community Cohesion Delivery Plan 2016-2017, a specific outcome on raising awareness on migration has been promoted, while key actions to increase the availability of information for migrants and the communities where they live have been undertaken. The specific plan concerning refugees and asylum seekers details collaborative actions in sectors such as housing, social care, education and employment. Concerning employment, programmes aiming at increasing the skills and opportunities for MRAs have been promoted in collaboration with non-profit organisations and educational institutions.

\subsection{Conclusion}

Our analysis of the UK context presents a very challenging environment for the integration of migrants, refugees and asylum seekers. The legislation of previous decades has been mainly based on increasing border control and decreasing entitlements to migrants, asylum seekers and refugees. Scarce attention has been placed upon strategies of integration and inclusion, based upon the idea (dismissed by several studies) that employment will constitute a pull factor in terms of migration and that the presence of migrants, in a period of economic crisis, affects the displacement of national workers. The main legislation has emphasised control of borders and have systematised a hostile environment towards migration, involving employers, landlords, banks, universities and even the NHS in controlling the presence of irregular migrants. This hostile environment has seen its peak in the Spring of 2018, in which the former Home Secretary has been forced to resign after the scandal of Windrush generation deportation and admitting to there being targets for the removal of irregular migrants. 
This lack of integration policies in the UK has been highly criticised by the UNHCR. Diversity has been mainly managed through racial equality and non-discrimination acts. But this does not seem enough to stimulate a process of integration and inclusion, which has been defined as a complex multidimensional path that affects different policy areas. The cross-cutting nature of policymaking in the field of integration has also generated tensions between the national and subnational level of government. Scotland and Wales, in fact, have promoted a different narrative and they have promoted integration strategies (Scotland) or specific delivery plans (Wales) in their devolved responsibilities, which not only include migrants and refugees but also asylum seekers and failed asylum applicants. Although local authorities and third sector organisations have a fundamental role in trying to address issues of integration, they have been affected by the austerity measures and their funds have been depleted in recent years. This alongside a lack of strategic coordination has generated a fragmented approach that risks undermining the aim of facilitating long-term inclusion.

Migrants, refugees and particularly asylum seekers represent a relatively easy target for austerity measures due to the increasingly negative narrative promoted by policy-makers and the UK media. Asylum seekers are the main targets of such policies. The prohibition of working, the lack of access to mainstream benefits and the freezing of support implemented in the last 20 years of legislation have deeply affected the lives of people that are waiting for their asylum claim to be processed. Increasing poverty and health inequalities among migrants with different legal statuses and between citizens and migrants have been increasing. Some of the rhetoric distinguishing between those who are deserving and undeserving in terms of welfare appears to lead us to question if there is now a tangible dividing line between the valorisation of high skilled immigrants who invest or work in jobs with occupational shortages compared to those with low skills or those who seek asylum. This division most probably will not improve with the results of the Brexit referendum. The risk of opting out from the European directives that have invested in promoting an adequate standard of living and the fair reception of migrants and refugees and in improving workers' rights will certainly have an impact on migrants in the UK.

However, rather than conclude that as a consequence of social, cultural and institutional change, the only future is a hostile environment for migrants, asylum seekers and refugees alongside a lack of integration, we argue that there is space to promote positive processes of integration. Through understanding the barriers and enablers that could facilitate or hinder inclusion into labour markets, it would hopefully be possible to counteract the hostile environment of today. However, the only way to test this idea thoroughly is to undertake a more in-depth analysis into what constrains or hinders integration processes into employment at macro (policies), meso (civil society and social partners) and micro (individuals) levels. This is our intention in the future stages of our research agenda. 


\section{References}

Ager, A., \& Strang, A. (2008). Understanding integration: A conceptual framework. Journal of Refugee Studies, 21(2), 166-191. https://doi.org/10.1093/jrs/fen016.

APPG. (2017). Refugees welcome? The experience of new refugees in the UK. All Party Parliamentary Group on Refugees.

Bakker, L., Cheung, S. Y., \& Phillimore, J. (2016). The asylum-integration paradox: Comparing asylum support systems and refugee integration in The Netherlands and the UK. International Migration, 54(4), 118-132. https://doi.org/10.1111/imig.12251.

Bales, K. (2013). Universal credit: Not so universal? Deconstructing the impact of the asylum support system. Journal of Social Welfare and Family Law, 35(4), 427-443. https://doi.org/10.108 0/09649069.2013.851168.

Bales, K. (2015). The 'essential living needs' of asylum seekers: Lessons learned from R (Refugee Action) v Secretary of State for the Home Department [2014] EWHC 1033. Journal of Social Welfare and Family Law, 37(2), 247-249. https://doi.org/10.1080/09649069.2015.1028159.

Blinder, S. (2017). Migration to the UK: Asylum (Migration Observatory Briefing). Oxford: COMPAS, University of Oxford.

Bloch, A. (2008). Refugees in the UK labour market: The conflict between economic integration and policy-led labour market restriction. Journal of Social Policy, 37(1), 21-36.

Cantle, T. (2001). Community cohesion: A report of the Independent Review Team. London: Home Office. Retrieved from http://tedcantle.co.uk/pdf/communitycohesion\%20cantlereport.pdf.

Cheung, S. Y., \& Phillimore, J. (2017). Gender and refugee integration: A quantitative analysis of integration and social policy outcomes. Journal of Social Policy, 46(2), 211-230. https://doi. org/10.1017/S0047279416000775.

Court, J. (2017). 'I feel integrated when I help myself': ESOL learners' views and experiences of language learning and integration. Language and Intercultural Communication, 17(4), 396-421.

Cummings, D. (2017, January 9). Dominic Cummings: How the Brexit referendum was won. The Spectator. Retrieved from https://blogs.spectator.co.uk/2017/01/ dominic-cummings-brexit-referendum-won/

Darling, J. (2016). Asylum in austere times: Instability, privatization and experimentation within the UK asylum dispersal system. Journal of Refugee Studies, 29(4), 483-505. https://doi. org/10.1093/jrs/few038.

Department for Exiting the European Union. (2017). The United Kingdom's exit from and new partnership with the European Union White Paper (Policy Paper). London: Department for Exiting the European Union. Retrieved from https://www.gov.uk/government/publications/ the-united-kingdoms-exit-from-and-new-partnership-with-the-european-union-white-paper.

Dwyer, P., Hodkinson, S., Lewis, H., \& Waite, L. (2016). Socio-legal status and experiences of forced labour among asylum seekers and refugees in the UK. Journal of International and Comparative Social Policy, 32(3), 182-198. https://doi.org/10.1080/21699763.2016.1175961.

Eurostat. (2018). Asylum quarterly report. Retrieved from http://ec.europa.eu/eurostat/statisticsexplained/index.php/Asylum_quarterly_report\#Further_Eurostat_information

Geddes, A. (2003). Migration and the welfare state in Europe. The Political Quarterly, 74(s1), 150-162. https://doi.org/10.1111/j.1467-923X.2003.00587.x.

Geddes, A., \& Scholten, P. (2016). Britain: The unexpected Europeanisation of immigration. In The politics of migration and immigration in Europe. Los Angeles: Sage.

Hansen, R. (2003). Migration to Europe since 1945: Its history and its lessons. The Political Quarterly, 74(s1), 25-38. https://doi.org/10.1111/j.1467-923X.2003.00579.x.

Home Office. (2017a). Permission to work and volunteering for asylum seekers (Guidance Report No. 7). London: Home Office. 
Home Office. (2017b). Syrian vulnerable resettlement scheme (VPRS) guidance for local authorities and partners. London: Home Office.

Joppke, C. (2004). The retreat of multiculturalism in the liberal state: Theory and policy1. The British Journal of Sociology, 55(2), 237-257. https://doi.org/10.1111/j.1468-4446.2004. 00017.x.

Koopmans, R. (2010). Trade-offs between equality and difference: Immigrant integration, multiculturalism and the welfare state in cross-national perspective. Journal of Ethnic and Migration Studies, 36(1), 1-26. https://doi.org/10.1080/13691830903250881.

MacIver, A. (2016). From refugees to workers. Mapping labour-market integration support measures for asylum seekers and refugees in EU Member States - The United Kingdom case study (Research Report No. Volume II-Literature Review and Country Case Studies). BertelsmannStiftung.

Mayblin, L. (2016). Complexity reduction and policy consensus: Asylum seekers, the right to work, and the 'pull factor' thesis in the UK context. The British Journal of Politics and International Relations, 18(4), 812-828. https://doi.org/10.1177/1369148116656986.

Meer, N., Peace, T., \& Hill, E. (2018). The governance and local integration of migrants and Europe's refugees: the UK, Scotland and Glasgow (Research Report No. WP2). University of Glasgow.

Montgomery, T., Calo, F., \& Baglioni, S. (2018). Claims making and the construction of the refugee crisis in Brexit Britain (Research Report). Glasgow: TransSOL Project.

Mulvey, G. (2015). Refugee integration policy: The effects of UK policy-making on refugees in Scotland. Journal of Social Policy, 44(2), 357-375. https://doi.org/10.1017/ S004727941500001X.

ONS. (2017). Migration levels: What do you know about your area? Retrieved from https://www. ons.gov.uk/peoplepopulationandcommunity/populationandmigration/internationalmigration/ articles/migrationlevelswhatdoyouknowaboutyourarea/2017-08-24

ONS. (2018). Long-term international migration estimates methodology. London: Office for National Statistics. Retrieved from https://www.ons.gov.uk/peoplepopulationandcommunity/populationandmigration/internationalmigration/methodologies/ longterminternationalmigrationestimatesmethodology.

Piętka-Nykaza, E. (2015). 'I want to do anything which is decent and relates to my profession': Refugee doctors' and teachers' strategies of re-entering their professions in the UK. Journal of Refugee Studies, 28(4), 523-543. https://doi.org/10.1093/jrs/fev008.

Sales, R. (2002). The deserving and the undeserving? Refugees, asylum seekers and welfare in Britain. Critical Social Policy, 22(3), 456-478.

Scholten, P., Collett, E., \& Petrovic, M. (2017). Mainstreaming migrant integration? A critical analysis of a new trend in integration governance. International Review of Administrative Sciences, 83(2), 283-302. https://doi.org/10.1177/0020852315612902.

Schuster, L., \& Solomos, J. (2004). Race, immigration and asylum - New labour's agenda and its consequences. Ethnicities, 4(2), 267-300.

Spencer, S., \& Sanders, S. (2016). Developing a strategic approach to integration in Wales (Research Report). Oxford: COMPAS, University of Oxford and Welsh Refugee Council.

Stewart, E., \& Mulvey, G. (2014). Seeking safety beyond refuge: The impact of immigration and citizenship policy upon refugees in the UK. Journal of Ethnic and Migration Studies, 40(7), 1023-1039. https://doi.org/10.1080/1369183X.2013.836960.

Strang, A. B., Baillot, H., \& Mignard, E. (2018). 'I want to participate.' Transition experiences of new refugees in Glasgow. Journal of Ethnic and Migration Studies, 44(2), 197-214. https://doi. org/10.1080/1369183X.2017.1341717.

van Breugel, I., \& Scholten, P. (2017). Mainstreaming in response to superdiversity? The governance of migration-related diversity in France, the UK and the Netherlands. Policy and Politics, 45(4), 511-526. https://doi.org/10.1332/030557317X14849132401769. 
Wallace, T. (2018). Policy-driven evidence: Evaluating the UK government's approach to immigration policy making. Critical Social Policy, 38(2), 283-301. https://doi. org/10.1177/0261018317726251.

Wright, C. F. (2017). Employer organizations and labour immigration policy in Australia and the United Kingdom: The power of political salience and social institutional legacies. British Journal of Industrial Relations, 55(2), 347-371. https://doi.org/10.1111/bjir.12216.

Wright, M., \& Bloemraad, I. (2012). Is there a trade-off between multiculturalism and sociopolitical integration? Policy regimes and immigrant incorporation in comparative perspective. Perspectives on Politics, 10(1), 77-95.

Open Access This chapter is licensed under the terms of the Creative Commons Attribution 4.0 International License (http://creativecommons.org/licenses/by/4.0/), which permits use, sharing, adaptation, distribution and reproduction in any medium or format, as long as you give appropriate credit to the original author(s) and the source, provide a link to the Creative Commons license and indicate if changes were made.

The images or other third party material in this chapter are included in the chapter's Creative Commons license, unless indicated otherwise in a credit line to the material. If material is not included in the chapter's Creative Commons license and your intended use is not permitted by statutory regulation or exceeds the permitted use, you will need to obtain permission directly from the copyright holder. 